\title{
Serum zinc levels in children with recurrent infections and atopic diseases
}

\author{
Surowicze stężenia cynku u dzieci z nawracającymi infekcjami i chorobami atopowymi
}

\author{
'Synevo Laboratory, Copernicus Memorial Hospital in Lodz, Łódź, Poland \\ ${ }^{2}$ Department of Paediatrics and Allergy, Korczak Paediatric Centre, Copernicus Memorial Hospital in Lodz, Medical University of Lodz, Lódź, Poland (Mikołaj Gwardys: 0RCID: 0000-0001-6552-0486) \\ Correspondence: Professor Iwona Stelmach, MD, PhD, Department of Paediatrics and Allergy, Korczak Paediatric Centre, Copernicus Memorial Hospital in Lodz, Medical University of Lodz, Piłsudskiego 71, \\ 90-329 kódź, Poland, tel.: + 484220747 26, fax: +48 42677 63 58, e-mail: alergol@kopernik.lodz.pl
}

\begin{abstract}
Zinc is a trace element necessary in many processes of cell metabolism and the catalytic activity of over 100 enzymes in humans. It plays a role in the immune system, protein synthesis, wound healing, DNA synthesis and cell division. Its immunomodulatory and anti-inflammatory effects have been evaluated in many studies. Zinc deficiency inhibits both innate and specific immunity, interferes with phagocytosis, intracellular killing and cytokine production by macrophages. Even minor zinc deficiencies can impair macrophage and neutrophil function. As one of the most important micronutrients included in many enzymes, zinc has an impact on the synthesis of proteins, hormones and red blood cells as well as proper functioning of the skin and mucous membranes. Zinc deficiency is a risk factor for developing asthma. Recent studies have shown that zinc supplementation can effectively suppress chronic inflammation and that zinc therapy effectively inhibits anaphylaxis. The aim of the study was to assess serum zinc levels in children hospitalised due to recurrent upper and lower respiratory tract infections and atopic diseases. The study showed lower zinc levels in $30 \%$ of children. This deficiency was greater in children with recurrent infections compared to children with atopic diseases. It was observed that the higher the specific IgE levels, the higher the serum zinc level in children. Our results suggest that hospitalised children are characterised by lower zinc levels, which may indicate its participation in the regulation of immune responses in patients with immune disorders.
\end{abstract}

Keywords: zinc, children, infections, atopy

Streszczenie Cynk jest pierwiastkiem śladowym niezbędnym ludziom w wielu procesach metabolizmu komórkowego, koniecznym dla katalitycznej aktywności ponad 100 enzymów. Odgrywa rolę w układzie odpornościowym, syntezie białek, gojeniu ran, syntezie DNA i podziałach komórkowych. Jego działanie immunomodulacyjne i przeciwzapalne zostało ocenione w wielu badaniach. Niedobór cynku hamuje zarówno odporność wrodzoną, jak i swoistą, zaburza fagocytozę, zabijanie wewnątrzkomórkowe oraz produkcję cytokin przez makrofagi. Nawet niewielkie niedobory cynku mogą upośledzać funkcje makrofagów i neutrofili. Cynk jako jeden z najważniejszych mikroelementów jest obecny w wielu enzymach, ma wpływ na syntezę białek, hormonów i krwinek czerwonych, prawidłowe funkcjonowanie skóry i błon śluzowych. Niedobór cynku jest czynnikiem ryzyka rozwoju astmy. Ostatnie badania dowodzą, że suplementy cynku mogą skutecznie tłumić przewlekłe stany zapalne, a włączenie tego mikroelementu do terapii skutecznie hamuje anafilaksję. Celem pracy była ocena stężenia cynku u dzieci hospitalizowanych z powodu nawracających infekcji górnych i dolnych dróg oddechowych oraz z powodu chorób atopowych. Stwierdzono, że u 30\% badanych dzieci stężenie tego pierwiastka jest obniżone. Niedobór cynku był większy u dzieci z nawracającymi infekcjami w porównaniu z dziećmi, u których stwierdzono chorobę atopową. Zaobserwowano, że im wyższe stężenie IgE swoistych, tym wyższe stężenie cynku w surowicy badanych dzieci. Wyniki sugerują, że u hospitalizowanych dzieci występują niższe stężenia cynku, co może wskazywać na jego udział w regulacji odpowiedzi immunologicznej, szczególnie u pacjentów wykazujących zaburzenia odpornościowe.

Słowa kluczowe: cynk, dzieci, infekcje, atopia 


\section{INTRODUCTION}

$\mathrm{Z}$ inc $(\mathrm{Zn})$ belongs to microelements. Cereal products, meat, cold meats and fish are the main source of zinc $^{(1)}$. As a cofactor of more than 300 enzymes, zinc contributes to normal function of many organs and tissues. It is also involved in the modulation of immune system mechanisms ${ }^{(2-4)}$. It enhances immune responses, among other things, by inducing monocyte adhesion to vascular endothelial cells, whereas a reverse effect is seen for its complexes with phosphates. Zinc deficiency inhibits both the innate and acquired immune response ${ }^{(5)}$, reduces neutrophil chemotaxis, impairs macrophage phagocytosis and generation of reactive oxygen species (ROS) by these cells ${ }^{(6)}$. Zinc ions induce the release of pro-inflammatory cytokines, such as interleukin 1 (IL-1), interleukin 6 (IL-6) and tumour necrosis factor $\alpha$ (TNF- $\alpha)$, as well as stimulate monocyte functions. It was found in vitro that high doses of zinc can inhibit T-cell function and leukocyte production of interferon- $\alpha$ (IFN-a). Therefore, it seems very important to monitor serum zinc levels. However, the exact zinc-mediated physiological mechanisms underlying immune system regulation are still largely unclear. There is growing evidence indicating that zinc acts as a signalling molecule, facilitating the transduction of different signalling cascades in response to extracellular stimuli ${ }^{(7)}$.

Zinc deficiency may increase eosinophil infiltration and is a risk factor for asthma, whereas zinc supplementation alleviates the symptoms of allergy ${ }^{(8-10)}$. Zinc chelators effectively inhibit anaphylaxis, while Zn supplements suppress chronic inflammation, as shown in studies using murine models. They may have important clinical implications in developing new therapeutic methods using zinc to inhibit inflammatory or allergic reactions ${ }^{(11)}$.

Considering the multidirectional effects of zinc on different cells, the aim of this study was to assess serum zinc levels in children with recurrent infections and atopic diseases in different age groups and different seasons of the year.

\section{MATERIALS AND METHODS}

A total of 120 children aged between 1 and 18 years (both sexes), hospitalised in the Department of Paediatrics and Allergy of the Korczak Paediatric Centre in Łódź between December 2017 and October 2018 due to recurrent respiratory infections and atopic diseases were included in the study. The children were classified into two groups: patients with recurrent infections and patients with atopy. Additionally, the study groups were subdivided into three age groups: 1-6, 7-12, and 13-18 years. The study was conducted during different seasons of the year. The study participants had their serum zinc levels and total immunoglobulin

\section{Measurement of zinc levels}

We used blood serum as material. Blood was collected from the basilic vein using a vacuum clot tube (Vacutainer, Sarsted). After coagulation, the blood was centrifuged. Zinc levels were measured with flame spectrometry, using Atomic Absorption Spectrometer PinAAcle 900T (PerkinElmer). A sample diluted with deionized water (to eliminate spectral interference) was used for zinc measurement. A blood sample diluted 4 times was introduced into the flame and run at $213.86 \mathrm{~nm}$, slit width $0.7 \mathrm{~mm}$, with a deuterium lamp used as background corrector. Each measurement was performed using a calibration curve. Absorbance of the curve was in the range of 0.0-0.8. A blank test was first performed using deionized water. The blank was run for the 0 point of the calibration curve. The solution in the flask was thoroughly mixed before calibration. Each measurement was performed twice and an arithmetic mean was calculated. The correlation coefficient for the calibration curve should not be less than 0.995 .

\section{Measurement of total IgE levels}

Total IgE levels were measured by electrochemiluminescence (ECLIA), using Cobas 6000 (Roche). A two-stage incubation of samples was performed: IgE in the sample, biotinylated monoclonal IgE-specific antibodies and ruthenium-labeled monoclonal IgE-specific antibodies formed a sandwich complex. Streptavidin-coated microparticles were added at the second stage of incubation. The reaction mixture was transferred to the measurement chamber, where microparticles were attracted to the electrode surface by a magnet. The voltage applied to the electrode induced electrochemiluminescence reaction and photon emission, which was measured using a photomultiplier. The results were read from a calibration curve prepared for a given analyser.

\section{RESULTS}

There were 60 patients of both sexes in each of the two groups. There were no statistically significant differences between the groups in terms of $\operatorname{sex}(p=0.855)$ or age $(p=0.024)$ (Tab. 1). A reference range for zinc levels of 70-120 $\mu \mathrm{g} / \mathrm{dL}$ was used for the interpretation of results $^{(12)}$. Low and reference zinc levels were found in 36 (30\%) and 83 (69\%) out of all 120 children. Only 1 patient presented with high zinc levels (1\%). Lower zinc levels were observed in children with recurrent infections ( $p=0.072$ ) (Fig. 1, Tab. 2). It was observed that zinc levels are lower in the first and third quarter of the year compared to the second and fourth quarter $(p<0.001)$ (Fig. 2). There was a statistically significant correlation between zinc levels and total IgE levels $(p=0.002)$ (Fig. 3). 


\begin{tabular}{|c|c|c|}
\hline $\begin{array}{c}\text { Age group } \\
\text { [years] }\end{array}$ & Sex & $\begin{array}{c}\text { Mean zinclevels } \\
{[\boldsymbol{\mu} \mathbf{g} / \mathbf{d L}]}\end{array}$ \\
\hline \multirow{4}{*}{$0-6$} & Girls & 77.1 \\
\cline { 2 - 3 } & Boys & 79.0 \\
\cline { 2 - 3 } & Total & 78.2 \\
\hline \multirow{4}{*}{$7-12$} & Girls & 68.2 \\
\cline { 2 - 3 } & Boys & 83.9 \\
\cline { 2 - 3 } & Total & 75.4 \\
\hline \multirow{4}{*}{$13-18$} & Girls & 80.5 \\
\cline { 2 - 3 } & Boys & 84.0 \\
\cline { 2 - 3 } & Total & 82.0 \\
\hline
\end{tabular}

Tab. 1. Classification of patients by age and sex

\begin{tabular}{|c|c|c|}
\hline Reason for hospital stay & Sex & $\begin{array}{c}\text { Mean zinc levels } \\
{[\boldsymbol{\mu} \mathbf{g} / \mathbf{d L}]}\end{array}$ \\
\hline \multirow{3}{*}{ Atopy } & Girls & 76.60 \\
\cline { 2 - 3 } & Boys & 83.00 \\
\cline { 2 - 3 } & Total & 80.01 \\
\hline \multirow{3}{*}{ Recurrent infections } & Girls & 74.15 \\
\cline { 2 - 3 } & Boys & 77.60 \\
\cline { 2 - 3 } & Total & 75.93 \\
\hline \multirow{3}{*}{ Total } & Girls & 75.35 \\
\cline { 2 - 3 } & Boys & 80.34 \\
\cline { 2 - 3 } & Total & 77.97 \\
\hline
\end{tabular}

Tab. 2. Classification of patients by the reason for hospital stay and sex

\section{DISCUSSION}

Although zinc deficiency is one of the most common nutrient deficiencies globally, the number of studies conducted in healthy populations to estimate its incidence is still very limited. This is largely due to technical difficulties in obtaining biologically reliable measurement of zinc levels. Different tests were used to diagnose zinc deficiency, but none of them proved suitable for the diagnosis $^{(13)}$. Serum zinc measurement is the most commonly used method. We used flame spectrometry, a reference method currently considered to be most sensitive, to measure zinc levels. No significant correlation was found between child's age and serum zinc levels, although there is evidence indicating such a relationship ${ }^{(14)}$. Vaghri et al. also found no such a relationship ${ }^{(15)}$. However, we found that zinc levels increased with age in boys, whereas no such a correlation was found in girls. A study conducted in 2018 showed a relationship between zinc levels and total IgE levels. Serum zinc levels were significantly lower in patients with atopic asthma compared to those with non-atopic asthma and healthy individuals. Highly

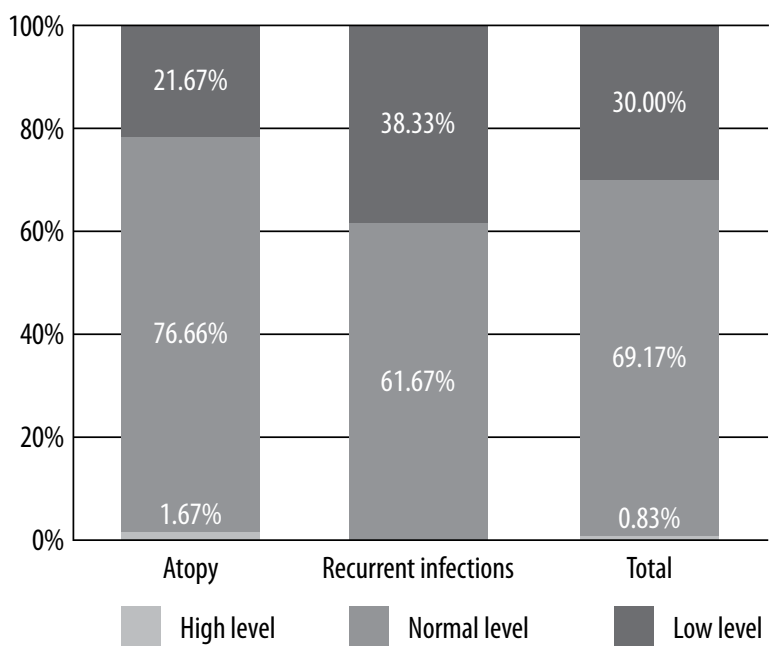

Fig. 1. Serum zinc levels in the subjects relative to the reference range $[\mu g / d L]$ by groups $(\mathrm{p}=0.072)$

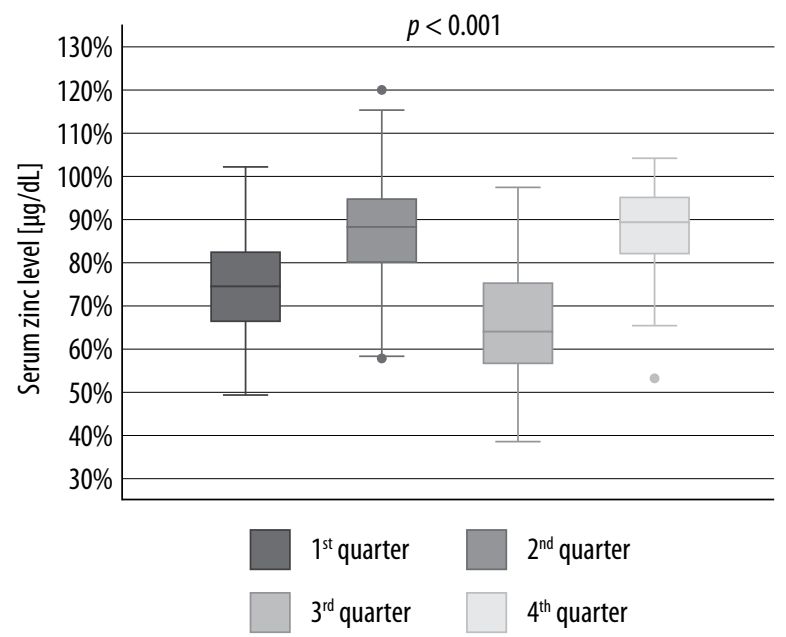

Fig. 2. Serum zinc levels in the subjects by quarter of the year

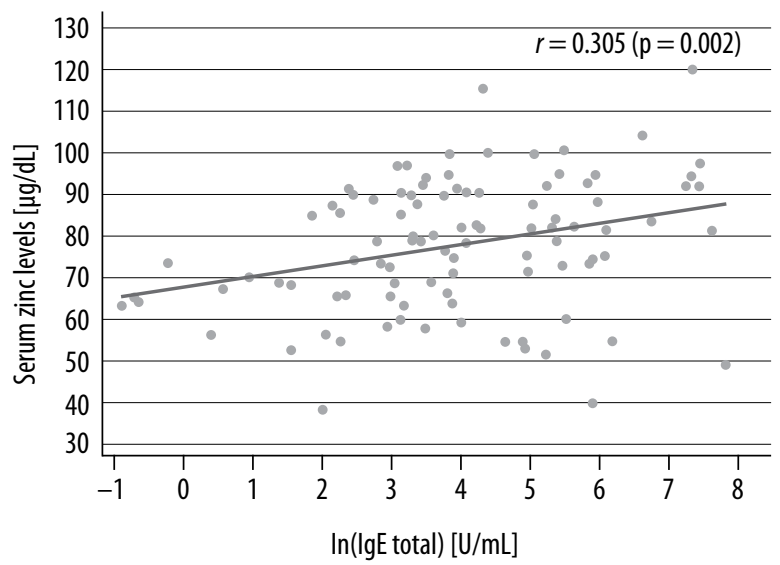

Fig. 3. Correlation between the logarithm of total IgE levels and serum zinc levels in study subjects 
significant correlations were found between zinc levels and total $\operatorname{IgE}$, and forced expiratory volume in 1 second $\left(\mathrm{FEV}_{1}\right)$ in atopic asthmatics ${ }^{(16)}$. We found that zinc levels were lower in children with recurrent infections than in children with atopic disease. The lowest zinc levels were observed in girls with recurrent infections, whereas the highest levels were detected in boys with atopic asthma. Recent studies have also shown that inclusion of zinc and iron in the therapy may have significant antiasthmatic effects, which may be attributed to their immunomodulatory and anti-inflammatory effects ${ }^{(17)}$. Zinc homeostasis is necessary for many aspects of immune function, including haematopoiesis, cell maturation and differentiation, cell cycle progression, and proper functioning of various immune cell populations ${ }^{(18)}$. It is suggested in the literature that reduced zinc levels correlate with elevated inflammatory mediators, including reactive oxygen species (ROS), matrix metalloproteinases (MMP), or antimicrobial peptides, such as calprotectin, causing tissue damage, especially in the liver, lungs and spleen ${ }^{(19,20)}$. Since cellular functions, such as intracellular killing of harmful pathogens, cytokine synthesis and ROS generation, depend on zinc, its deficiency leads to impairment of these processes. Zinc deficiency has also negative effects on maturation and activity of $\mathrm{T}$ and $\mathrm{B}$ cells, which is due to the dysregulation of basic biological functions at a cellular level. In the case of T cells, the Th1/Th2 balance is impaired, which leads to increased production of Th2 cells and, consequently, increased severity of allergic reactions $^{(21)}$. It has been recently demonstrated that zinc deficiency impairs some neutrophil functions, including phagocytosis, oxidative burst, degranulation and cytokine production, and chemotaxis ${ }^{(22-24)}$. Zinc undoubtedly plays a key role in regulating immune function. Therefore, it seems reasonable to conduct further detailed studies on the consequences of zinc deficiency in different clinical entities.

\section{CONCLUSIONS}

1. Low serum zinc levels were found in $30 \%$ of children from the Łódź region, hospitalised in the Department of Paediatrics and Allergy. This deficiency was higher in children with recurrent infections compared to children with atopic disease.

2. Zinc levels depended on the quarter of the year, with the lowest levels reported in the first and the third quarter of the year.

3. Higher total IgE levels correlated with higher serum zinc levels in children.

4. There was no statistically significant relationship between zinc levels and sex or age.

\section{Conflict of interest}

The authors do not report any financial or personal connections with other persons or organisations, which might negatively affect the contents of this publication and/or claim authorship rights to this publication.

\section{Funding/Support and role of the sponsor}

The study was supported by the Medical University of Lodz, Poland, grant No 503/2-056-01/503-21-001.

\section{References}

1. Gawęcki J, Hryniewiecki L (eds.): Żywienie człowieka. Vol. 1: Podstawy nauki o żywieniu. Wydawnictwo Naukowe PWN, Warszawa 2000.

2. Rink L, Kirchner H: Zinc-altered immune function and cytokine production. J Nutr 2000; 130 (5S Suppl): 1407S-1411S.

3. Rink L, Gabriel P: Zinc and the immune system. Proc Nutr Soc 2000; 59: 541-552.

4. Wellinghausen N: Immunobiology of gestational zinc deficiency. Br J Nutr 2001; 85 Suppl 2: S81-S86.

5. Bailey RL, West KP Jr, Black RE: The epidemiology of global micronutrient deficiencies. Ann Nutr Metab 2015; 66 Suppl 2: 22-33.

6. Krzysik M, Biernat J, Grajeta H: Wpływ wybranych składników odżywczych pożywienia na funkcjonowanie układu odpornościowego. Cz. II. Immunomodulacyjne działanie witamin i pierwiastków śladowych na organizm człowieka. Adv Clin Exp Med 2007; 16: 123-133.

7. Hojyo S, Fukada T: Roles of zinc signaling in the immune system. J Immunol Res 2016; 2016: 6762343.

8. Richter M, Bonneau R, Girard MA et al.: Zinc status modulates bronchopulmonary eosinophil infiltration in a murine model of allergic inflammation. Chest 2003; 123 (Suppl): 446S.

9. Zalewski PD, Truong-Tran AQ, Grosser D et al.: Zinc metabolism in airway epithelium and airway inflammation: basic mechanisms and clinical targets. A review. Pharmacol Ther 2005; 105: 127-149.

10. Riccioni G, D'Orazio N: The role of selenium, zinc and antioxidant vitamin supplementation in the treatment of bronchial asthma: adjuvant therapy or not? Expert Opin Investig Drugs 2005; 14: 1145-1155.

11. Nishida K, Uchida R: Role of zinc signaling in the regulation of mast cell-, basophil-, and T cell-mediated allergic responses. J Immunol Res 2018; 2018: 5749120.

12. Jakubowski Z, Kabata J, Kalinowski L et al.: Badania laboratoryjne w codziennej praktyce. MAKmed, Gdańsk 1998.

13. International Zinc Nutrition Consultative Group (IZiNCG); Brown KH, Rivera JA, Bhutta Z et al.: International Zinc Nutrition Consultative Group (IZiNCG) technical document \#1. Assessment of the risk of zinc deficiency in populations and options for its control. Food Nutr Bull 2004; 25 (Suppl 2): S99-S203.

14. Vuralli D, Tumer L, Hasanoglu A: Zinc deficiency in the pediatric age group is common but underevaluated. World J Pediatr 2017; 13: 360-366.

15. Vaghri Z, Barr S, Wong $\mathrm{H}$ et al.: Age-based differences in hair zinc of Vancouver preschoolers. Biol Trace Elem Res 2008; 126 Suppl 1: S21-S30.

16. Mohamed NA, Rushdy M, Abdel-Rehim ASM: The immunomodulatory role of zinc in asthmatic patients. Cytokine 2018; 110: 301-305.

17. Jehangir A, Shahzad M, Shahid K et al.: Zinc and iron complexes of oleanolic acid, (OA) attenuate allergic airway inflammation in rats. Inflammopharmacology 2019; 27: 1179-1192. 
18. Haase H, Rink L: Multiple impacts of zinc on immune function. Metallomics 2014; 6: 1175-1180.

19. Wessels I, Cousins RJ: Zinc dyshomeostasis during polymicrobial sepsis in mice involves zinc transporter ZIP14 and can be overcome by zinc supplementation. Am J Physiol Gastrointest Liver Physiol 2015; 309: G768-G778.

20. Knoell DL, Julian MW, Bao $S$ et al.: Zinc deficiency increases organ damage and mortality in a murine model of polymicrobial sepsis. Crit Care Med 2009; 37: 1380-1388.

21. Wessels I, Haase H, Engelhardt G et al.: Zinc deficiency induces production of the proinflammatory cytokines IL- $1 \beta$ and TNFo in promyeloid cells via epigenetic and redox-dependent mechanisms. J Nutr Biochem 2013; 24: 289-297.
22. Wessels I, Maywald M, Rink L: Zinc as a gatekeeper of immune function. Nutrients 2017; 9. pii: E1286.

23. Hasan R, Rink L, Haase H: Zinc signals in neutrophil granulocytes are required for the formation of neutrophil extracellular traps. Innate Immun 2013; 19: 253-264.

24. Hasan $\mathrm{R}$, Rink L, Haase $\mathrm{H}$ : Chelation of free $\mathrm{Zn}^{2+}$ impairs chemotaxis, phagocytosis, oxidative burst, degranulation, and cytokine production by neutrophil granulocytes. Biol Trace Elem Res 2016; 171: 79-88. 